\title{
Review
}

\section{The Appendix in Parkinson's Disease: From Vestigial Remnant to Vital Organ?}

\author{
Bryan Killinger ${ }^{\mathrm{a}}$ and Viviane Labrie ${ }^{\mathrm{b}, \mathrm{c}, *}$ \\ ${ }^{a}$ Department of Neurological Sciences, Rush Medical College, Chicago, IL, USA \\ ${ }^{\mathrm{b}}$ Center for Neurodegenerative Science, Van Andel Research Institute, Grand Rapids, MI, USA \\ ${ }^{\mathrm{c}}$ Division of Psychiatry and Behavioral Medicine, College of Human Medicine, Michigan State University, \\ Grand Rapids, MI, USA
}

\begin{abstract}
Parkinson's disease (PD) has long been considered a brain disease, but studies now point to the gastrointestinal (GI) tract as a potential starting point for PD. In particular, the human vermiform appendix has been implicated in PD. The appendix is a tissue rich in immune cells, serving as part of the gut-associated lymphoid tissue and as a storehouse for the gut microbiome. The functions of the appendix converge with recent evidence demonstrating that gut inflammation and shifts in the microbiome are linked to PD. Some epidemiological studies have linked removal of the appendix to lowered PD risk, though there is controversy among these associations. What is apparent is that there is an abundance of aggregated forms of $\alpha$-synuclein in the appendix relevant to PD pathology. $\alpha$-Synuclein pathology is thought to propagate from gut to brain via the vagus nerve, which innervates GI tract locations, including the appendix. Remarkably, $\alpha$-synuclein aggregates in the appendix occur not only in PD patients, but are also present in healthy individuals. This has led to the proposal that in the appendix $\alpha$-synuclein aggregates are not unique to PD. Moreover, the molecular events leading to PD and the mechanisms by which $\alpha$-synuclein aggregates transfers from gut to brain may be identifiable in the human appendix. The influence of the appendix on GI inflammation, autoimmunity, microbiome storage, and the lymphatic system may be yet unexplored mechanisms by which the appendix contributes to PD. Overall, the appendix represents a promising tissue site to advance our understanding of PD pathobiology.
\end{abstract}

Keywords: $\alpha$-Synuclein, appendix, gastrointestinal tract, Parkinson's disease, vagus nerve

\section{INTRODUCTION}

The vermiform appendix is a narrow, finger-shaped pouch connected to the end of the cecum in the gastrointestinal (GI) tract. Although the appendix has often been referred to as vestigial organ, that interpretation is now changing. The appendix serves as an immune tissue in the gut that is also capable of regulating the intestinal microbiome [1-4]. Recent

\footnotetext{
*Correspondence to: Viviane Labrie, Center for Neurodegenerative Science, Van Andel Research Institute, Grand Rapids, MI, 49503, USA. E-mail: viviane.labrie@vai.org.
}

evidence suggests that the vermiform appendix may contribute to the initiation of Parkinson's disease (PD). The appendix was shown to house an abundance of aggregated $\alpha$-synuclein ( $\alpha$-syn), which is a major component of the hallmark Lewy pathology in the PD brain $[5,6]$. Aggregated $\alpha$-syn can propagate between neurons, seeding itself into healthy neurons to induce Lewy pathology and neuronal death $[7,8]$. $\alpha$-Syn aggregates have been detected in the GI tract early in the disease [6,9] and, in experimental models, are capable of reaching the brain via the vagus nerve [10-12]. The appendix is innervated by the vagus nerve and the prevalence of the $\alpha$-syn aggregates 
in this tissue points to a potential route for synucleinopathy to propagate from gut to brain. Moreover, the involvement of the appendix in immunosurveillance, microbial storage, and association with the lymphatic system may be alternative or additional mechanisms of appendiceal contributions to PD. There have been epidemiological studies demonstrating that early removal of the appendix is associated with a reduced risk for PD [5, 13]. Though this finding is not replicated in some studies [14-17] (described in detail in recent reviews [18-20]), ascertainment of medical information and study follow-up length may contribute to this discrepancy. In this review, we examine the possible mechanisms by which the appendix may contribute to PD. Overall, the appendix offers an interesting starting point for exploring gut contributions to the initiation and progression of PD.

\section{THE PURPOSE OF THE APPENDIX: IMMUNOSURVEILLANCE AND BACTERIAL STORAGE}

The appendix is an unusual tissue because since its identification more than 400 years ago and until the 21 st century, its function in the human body was not known. Charles Darwin first theorized that the appendix was a useless remnant of evolution, proposing that it previously served in the digestion of an ancestral diet of leaves [21]. However, the proposition that the appendix is an intestinal region lacking biological purpose is countered by contemporary evolutionary studies. The appendix was found to have independently evolved at least 32 times among mammals, and its retention once evolved suggests a selective advantage in mammalian taxa [22]. The cecal appendix or appendix-like structures are present in a variety of primates, rodents, marsupials, and other mammals, as well as in certain types of birds and fish $[22,23]$. Evolutionary changes in diet do not appear to be related to the appearance of the appendix in mammals [22]. Rather, recent evidence supports that the appendix has an important role in the development and preservation of the intestinal immune system and that it acts as a storage site for the intestinal microbiome [1-4, 24].

The appendix is rich in immune cells having a primary function in the detection and removal of pathogens. As part of the gut-associated lymphoid tissue (GALT), the appendix contains cells (e.g., microfold (M) cells) in the epithelial barrier that sample luminal bacteria and other antigens [25]. Antigens are then presented to adaptive immune cells within lymphoid follicles, which furthers the development of antibody repertoires and evokes immune responses [2]. The appendix has a unique lymphocyte content compared to the rest of the GI tract and GALT, including a distinct abundance of natural killer $\mathrm{T}$ cells, activated T cells (expressing CD45R) [26], and IgAand IgG-producing B-cells [27, 28], which are important effectors in the immune responses to microbial agents.

The appendix is also regarded as a "safe house" for commensal gut bacteria [2, 3, 29]. In the appendix, there is a two-layer mucus barrier consisting of a firmly attached inner layer devoid of bacteria to protect the host and a luminal layer containing the microbial biofilm $[31,32]$. The microbial biofilm of the appendix is shielded from intestinal clearance and peristalsis, and can facilitate the (re)colonization of the gut after a GI infection [2, 3, 29]. The biofilm in the appendix consists of a microbial mixture enclosed in a complex and self-produced polymeric matrix, which protects the appendiceal microbiome from passing contaminants and colonization by pathogenic bacteria $[3,30]$. Furthermore, the appendix is a site for the generation of IgA-secreting plasma cells, which shape microbiome composition throughout the entire large intestine [4]. IgA and mucin formation is also high within the appendix; these substances control the growth of bacteria and prevents their invasion of the host $[28,31,32]$. Hence, the appendix is an immunological organ that has an ideal location in the GI tract to house and alter the gut microbiome.

\section{PARKINSON'S DISEASE FROM GUT TO BRAIN}

Growing evidence suggests that PD may initiate in the GI tract. In PD patients, the non-motor symptom of GI dysfunction (i.e., constipation) often appears much earlier in the disease, predating the onset of motor symptoms by as many as 20 years $[33,34]$. PD pathology, consisting of aggregated $\alpha$ syn, has been detected in enteric neurons of the GI tract in prodromal PD patients [6, 9]. Furthermore, pathogenic accumulation of $\alpha$-syn in the GI tract is able to ascend to the brain via the vagus nerve in experimental models [10]. Numerous experimental studies have shown that misfolded $\alpha$-syn can propagate from cell-to-cell, triggering the formation of Lewy-like aggregates in neurons $[35,36]$. The arrival of aggregated $\alpha$-syn from the GI tract 
is consistent with neuropathological observations in humans that one of the first places to exhibit Lewy pathology in many (but not all) PD patients is the dorsal motor nucleus that connects the vagus nerve innervating the gut to the brainstem [37]. A truncal vagotomy, in which the vagus nerve connecting the GI tract to the brain is severed, has been associated with lower PD risk in some epidemiological studies [38-40]. The gut-brain transport of $\alpha$-syn pathology is likely bidirectional because rodents overexpressing $\alpha$-syn in the midbrain also show subsequent GI $\alpha$-syn pathology [41]. Nonetheless, an imaging study showed that neuronal dysfunction in the peripheral autonomic system, including in the GI tract, precedes the destruction of nigral dopaminergic neurons in individuals with prodromal PD [42]. Hence, the early appearance of $\alpha$-syn aggregates and neuronal impairments in the GI tract $[6,9,42]$, along with the ability of $\alpha$-syn pathology to ascend the vagus nerve to the brain $[10,11]$, supports a potential GI tract origin for PD [43-45].

\section{THE APPENDIX IS A RESERVOIR FOR $\alpha$-SYN AGGREGATES}

In prodromal PD and in PD patients, there are higher levels of aggregated (proteinase K-resistant) $\alpha$-syn in the appendix relative to other GI tract regions [6]. Moreover, $\alpha$-syn aggregates are also prevalent in the mucosa and enteric plexuses of the healthy human appendix [5]. Aggregated $\alpha$-syn was shown to be present at all age groups in the healthy human appendix, including young individuals $(<20$ years of age), and it was observed in individuals with a normal appendix and in individuals with an inflamed appendix [5]. $\alpha$-Syn aggregates were particularly enriched in nerve terminals of myenteric plexuses of the appendix [5], which are innervated by the vagus nerve, and thus may be a means for gut to brain propagation. Analysis of the specific forms of $\alpha$-syn present in the appendix of healthy people and PD patients revealed that the appendix contained an abundance of truncated $\alpha$-syn, exceeding that in the substantia nigra of both PD and healthy subjects [5]. $\alpha$-Syn truncation products are enriched in Lewy bodies [46-48] and can serve as potent seeds for rapid $\alpha$-syn aggregation in experimental models [49]. $\alpha$ Syn truncation products identified in the appendix contained an intact NAC-domain, which is necessary and sufficient for $\alpha$-syn aggregation [50, 51]. Indeed, elimination of the $\mathrm{N}$ - and/or C-terminal enhances aggregation kinetics of $\alpha$-syn in vitro and in vivo [49, $52,53]$, suggesting that the prevalence of truncated $\alpha$-syn in the appendix likely makes this tissue prone to PD-relevant pathology. While both the healthy and PD appendix contained abnormally truncated forms of $\alpha$-syn, the truncated and insoluble $\alpha$-syn proteoforms were more abundant in the PD appendix [5]. Overall, these findings suggest that the appendix acts as a reservoir for pathogenic $\alpha$-syn that could propagate from gut to brain, and indicates that healthy and PD individuals may differ in their ability to handle $\alpha$-syn aggregates in the appendix.

The discovery that $\alpha$-syn aggregates are prevalent in the appendix of healthy individuals (even in young people under 20 years old who presumably lack CNS pathology) signifies that $\alpha$-syn aggregation in the appendix is a normal biological phenomenon. In support, cell bodies and processes bearing $\alpha$-syn aggregates in the appendix appear morphologically intact, in contrast to CNS neurons with Lewy bodies, which often have abnormal morphology. The purpose of $\alpha$-syn aggregates in the appendix may be to recruit immune cells and/or to respond to pathogens [54-57]. An increase in $\alpha$-syn occurs in the intestinal wall of children in response to GI infection and remains elevated even 6 months after the resolution of infection [54]. $\alpha$-Syn expression has also been shown to increase in the rodent brain in response to West Nile Virus and Venezuelan equine encephalitis, and an absence of $\alpha$-syn exacerbated the lethal effects of viral encephalitis [55, 56]. Furthermore, gut infections by E. coli that produce the amyloid protein curli promote $\alpha$-syn aggregation in both the gut and brain [58]. Hence, the abundance of $\alpha$-syn aggregates in the appendix may be closely related to its role as a microbial niche.

Although $\alpha$-syn aggregates were observed in the appendix it is unclear if they are neurotoxic. Similar accumulation of $\alpha$-syn aggregates and of the $\mathrm{N}$ and/or C-terminal truncated $\alpha$-syn proteoforms identified in the appendix are neurotoxic in the brain [5]. In addition, $\alpha$-syn in the appendix is immunoreactive for pSer129 $\alpha$-syn, which is a marker of pathological inclusions [5]. Therefore, if $\alpha$-syn aggregates from the appendix were to transit to the brain this may result in neurodegeneration seen with PD. Given the prevalence of the $\alpha$-synuclein aggregates in the normal appendix, an escape of $\alpha$-synuclein seeds to the brain must be a relatively rare event. A transfer of $\alpha$-syn aggregates from appendix to brain that has pathogenic consequences would likely require other biological processes to be compromised in PD, 
such as pathways that suppress the accumulation and spread of $\alpha$-syn in the appendix. A "secondary hit" or a "facilitator" (genetic, epigenetic, and/or environmental risk factor) that potentiates the accumulation and uninhibited propagation of $\alpha$-syn to the brain may be what distinguishes a PD patient from a healthy individual. Such facilitators may be identified in future molecular studies of the appendix.

The gut has been hypothesized to be a starting point for PD pathogenesis, but several findings have brought that theory into question. In particular, work from Beach et al. (2016) systematically characterized $\alpha$-syn pathology throughout the body in hundreds of autopsied cases and did not find an instance of gutonly pathology $[59,60]$. This is a crucial finding in the field, because for pathology to originate in the gut, one would expect to find cases where pathology was exclusively located in the GI tract. However, Beach et al. (2016) did not assess pathology in the appendix [60]. The detection of $\alpha$-syn aggregates in the appendix of healthy patients may address this weakness in the theory. If appendix-derived $\alpha$-syn aggregates prove to be pathogenic, then their location at a vagal site lends an opportunity for propagation to the brain and PD initiation. Animal models have demonstrated that aggregated $\alpha$-syn must occur in specific gut locations, particularly those innervated by the vagus nerve, in order to spread to the brain [12]. The appendix may provide a source of pathological $\alpha$ syn with access to the vagus nerve to initiate disease, but the progression of pathology likely requires other second-hit factors (e.g., environmental, genetic, epigenetic) as propagation of $\alpha$-syn pathology plateaus, and even recedes, in normal (wild-type) animals [61, 62].

\section{MICROBIOME REGULATION BY THE APPENDIX}

The gut microbiota is increasingly recognized to be critical for brain processes (such as neurogenesis, myelination, and microglial activation) and is capable of modulating behavior and cognition [63]. Commensal microbes produce a myriad of neurochemicals that are fundamental to human brain health and have been implicated in neuropsychiatric and neurodegenerative diseases [63]. Gut microorganisms synthesize numerous neurotransmitters, including $\gamma$-aminobutyric acid (GABA), serotonin, and dopamine, and neuromodulators like short-chain fatty acids and bile acids, and they also promote serotonin biosynthesis from host colonic enterochromaffin cells [64-66]. Metabolites secreted by the microbiome can activate the vagus nerve directly (via short-chain fatty acids or endotoxins) or indirectly (via enteroendocrine cells signaling), which alter neuronal activity in numerous brain areas. For example, activation of the GI branches of the vagus nerve alters dopamine neurotransmission in the substantia nigra and influences reward behaviors [67]. Bacterial-produced endotoxins also activate of the vagus nerve in the gut, which is reciprocated by a marked stimulation of brain-mediated anti-inflammatory effects, protecting against microbial-induced sepsis [68]. Furthermore, the microbiome has direct effects on the immune system, affecting the amounts of cytokines, host immunity, and inflammation both in the periphery and the brain [63]. Short-chain fatty acids produced by the microbiome have been shown to regulate the generation and recruitment of innate and adaptive immune cells $[69,70]$ and, in a PD mouse model, the activation state of brain microglia [45]. Thus, the bidirectional communication between gut microbes and the brain involves neuroactive metabolites, vagus nerve stimulation, and the immune system. As an immune tissue that houses the microbiome, the appendix may represent an optimal starting point for understanding the effects of dysbiosis on the brain.

Microbiome abnormalities in the human appendix may be relevant to PD. The human appendix contains a highly diverse microbiota present in a thick biofilm, which helps the bacteria withstand biological, chemical, and physical stresses [71]. Because the appendix is considered to be capable of repopulating the microbiome in the small and large intestine [4, 29], microbiome changes relevant to PD, or the housing of pro-inflammatory bacteria in the appendix, could signify a dispersion throughout the intestine. Altered release of anti-microbial IgA-secreting cells from the appendix would also cause intestinal dysbiosis [4]. Moreover, metabolites secreted by the microbiome of the appendix would have access to the arsenal of immune cells within this lymphoid tissue. Indeed, the interaction with commensal microbes helps the GALT in developing an adequate immune response to pathogens and enhances intestinal barrier function [72-74].

The microbial taxa within the appendix has been shown to differ from that of the rectum and of fecal samples, suggesting that a distinctive appendix microbiome exists [75, 76]. Numerous studies support that there are microbiome changes 
in PD stool, even in drug-naive cases [77-81]. The relative abundance of different microbes has been associated with the severity of motor and nonmotor impairments in PD [77, 78], and preliminary double-blind placebo controlled trials suggest a beneficial effect of consuming probiotic mixtures on PD patient symptoms, including motor symptoms, constipation, and metabolism [82, 83]. Fecal microbiota transplantation has been shown to be protective against 1-methyl-4-phenyl-1,2,3,6tetrahydropyridine (MPTP)-induced neurotoxicity in mice [84, 85], and it is currently being tested in clinical trials (NCT03808389). Repopulating the appendix with a healthy microbiome may be an innovative direction for future therapeutics. This could be a better therapeutic approach than current fecal transplants because of the ability of the appendix to repopulate the flora in the small and large intestine, and resist harmful changes in the GI tract microbiome (e.g., acute GI tract infections) [2,86]. The abundant and shielded biofilm matrix in the appendix $[3,30]$ may protective for the transplanted bacteria, allowing for a long lasting effect of the microbiome transplant. Routine shedding of fragments of the biofilm from appendix could act as seeds for the inoculation and renewal of the intestine with the transplanted healthy microbiome.

\section{IMMUNE SYSTEM DEVELOPMENT, PRESERVATION, AND ACTIVATION}

A primary constituent of the appendix is lymphoid follicles, which contain densely packed lymphocytes, $\mathrm{B}$ cells, and $\mathrm{T}$ cells, along with macrophages and dendritic cells. In early infancy, the timing of the development of lymphoid follicles and antibody production in the gut is stimulated by the presence of commensal bacteria [87-89]. Indeed, bacterial translocation in the normal human appendix parallels local immune system development in the first year of life [72]. Germ-free mice, which lack a microbiome, have an appendix (called the cecal patch in mice) that is substantially reduced in size, is deficient in lymphocytes, lacks anti-microbial IgA levels, and has impaired maturation of lymphoid follicles [4, 90, 91]. Hence, normal development of the appendix immune system is closely intertwined with the microbiome. Furthermore, early-life immune system activation, including by microbial cell wall components, affects neuronal cell proliferation in the hippocampus and cortex, which has subsequent consequences on adult behavior and cognition [92, 93]. This appears to occur during a critical time window, because studies in germ-free mice demonstrate that the introduction of a normal microbiota in adulthood does not reverse the neurodevelopmental or behavioral consequences [94]. Thus, abnormal immune system activation resulting from microbiome shifts in the appendix during a critical neurodevelopmental period may affect brain health in later adult life. If such effects in early development were to modify the vulnerability or number of dopaminergic neurons in the substantia nigra, this may influence predisposition to developing PD [95].

GALT is found throughout the GI tract, so what makes the appendix unique for the pathoetiology of PD? The diversity of immune cells in the appendix is unique amongst other GALT tissues. T cell populations are particularly different in the appendix relative to other GALT intestinal tissues. The appendix contains the highest amount of regulatory T cells (Tregs; $\mathrm{CD} 4^{+}, \mathrm{C} 25^{\text {high }}, \mathrm{CD} 127^{{ }^{\circ} \mathrm{w} / \text { neg }^{2}}$ FOXP3), compared to gastric, small and large intestinal regions [96]. Treg cells are centrally involved maintaining tolerance to self-antigens and preventing autoimmune diseases. Naïe helper (CD4+) and cytotoxic (CD8+) T cells are also higher in the appendix relative to Peyer's patches, the small intestine, and colon, whereas effector memory T cells are lower in the appendix [97]. In the appendix, the naive CD8+ T cell population substantially decreases with age (over 50\% loss), which is also observed in other GALT tissues [97]. Intraepithelial lymphocytes associated with $\mathrm{M}$ cells in the GALT are the first to contact luminal antigens taken up from the intestine [98]. The appendix has a much higher enrichment of T cells among these intraepithelial lymphocytes (95\%) than Peyer's patches $(65 \%)$ [98]. Intraepithelial $\mathrm{T}$ cells in the appendix, relative to other intestinal regions, have also been shown to be enriched in a distinct population of natural killer $\mathrm{T}$ cells $\left(\mathrm{NK} 1.1^{+} \mathrm{CD}^{+}\right)$, which rapidly produce cytokines following activation, and $\mathrm{T}$ cells with a B cell marker $\left(\mathrm{B} 220^{+} \mathrm{CD} 3^{+} \mathrm{T}\right.$ cells), which play a role in autoimmunity [26, 99]. Furthermore, the appendix is a major site of $\operatorname{IgA}$ production in the gut $[4,27]$. B cell-derived plasmablasts that secrete IgA migrate from the appendix to small and large intestinal regions [4]. Removal of the appendix results in a marked decrease in serum IgA concentrations, supporting its important role in maintaining IgA levels [100]. Because of the crucial role of $\operatorname{IgA}$ in regulating the gut microbiome [101], the appendix is likely an important tissue for host-microbiome interactions. 
Therefore, the appendix features an abundance of $\mathrm{T}$ cell types and IgA-secreting cells that can impact autoimmunity, inflammation, and the microbiome in the GI tract.

Recently, PD has been proposed to be an autoimmune disorder, involving the erroneous attack of endogenous $\alpha$-syn. Several autoantibodies and disturbances in T-cell function have been found in PD, including an increase in $\mathrm{T}$ cells reactive to the $\mathrm{N}$ - and C-terminus of $\alpha$-syn $[102,103]$. In addition to Treg cells, B1 lymphocytes $\left(\mathrm{CD}^{+} \mathrm{B}\right.$ cells) are preferentially found in the appendix, relative to other areas of the GI tract [96, 104, 105]. B1 lymphocytes cells are specialized in the production of IgM, which have a low affinity to a broad spectrum of antigens and which produce anti-self antibodies [106]. Autoantibodies produced by $\mathrm{B} 1$ cells in turn stimulate and modulate $\mathrm{T}$ cell activity. $\mathrm{B} 1$ cells and increased amounts of IgM are frequently implicated in autoimmune diseases [107]. Deficient immune suppression by Treg cells is also centrally involved in the pathogenesis of autoimmune diseases [108]. Consequently, the prevalence of B1 cells and Tregs in the appendix alongside an abundance of $\alpha$-syn aggregates raises the possibility that autoimmunity to $\alpha$-syn is triggered in the appendix. Furthermore, natural antibodies against amyloidogenic toxic peptides decline with age and with advancing PD and Alzheimer's disease [109, 110]. If there were to be an erosion of natural antibody production against $\alpha$-syn in the appendix, this could result in the excessive accumulation and propagation of $\alpha$-syn aggregates.

The appendix may also contribute to PD by modifying gut inflammation and the risk of developing inflammatory bowel diseases. High levels of cytokines and inflammatory markers are observed in the colon of PD patients [80, 111]. Several recent epidemiological studies have also shown an increased associated risk for PD in individuals with inflammatory bowel diseases (IBD): ulcerative colitis and Crohn's disease [112-115]. Moreover, IBD patients exposed to anti-TNF therapy (used to dampen gut inflammation) had a $78 \%$ reduction in the incidence of PD [114]. Chronic inflammation of the appendix is observed in ulcerative colitis, and in some individuals, appendiceal orifice inflammation precedes ulcerative colitis [116]. More than 30 studies have investigated the link between appendectomy and ulcerative colitis, with the majority showing that early removal of the appendix is associated with a lowered risk of ulcerative colitis $[117,118]$. It has also been shown that the protective effect of appendectomy is related to the removal of appendiceal inflammation rather than the surgery itself $[117,119]$. Appendiceal inflammation may produce an excess of $\alpha$-syn aggregates that increases PD risk. Indeed, chronic colitis in mice due to dextran sodium sulfate exposure has been shown cause an accumulation of enteric $\alpha$-syn aggregates and, in a genetic model of PD, a subsequent loss of nigral neurons [120, 121]. The removal of the appendix (cecal patch) in mice models protects against the development of colitis [122-125]. Together, these studies suggest that the appendix is a priming site for the development of ulcerative colitis. Therefore, removal of the appendix may decrease the risk of both PD and colitis by eliminating a chronic source of GI inflammation.

\section{THE BLOOD-BRAIN-BARRIER, LYMPHATIC SYSTEM, AND THE APPENDIX}

Blood-brain-barrier (BBB) dysfunction is often mediated by neuroinflammation and occurs in PD. The brain was recently discovered to have lymphatic vasculature that was found to degenerate in the aging brain [126-130]. The BBB and brain lymphatic vasculature are considered to serve as gateways for various signals entering and exiting the brain. These signals include circulating immune cells and soluble molecules (such as hormones, metabolites, and neurotransmitters) that originate from the host or microbiome [130, 131]. As such, the BBB and/or brain lymphatic system may be a means by which immune cells and microbial signals derived from the gut reach the brain. Conversely, signals from the brain may also travel to the periphery via the blood and lymphatic system [132].

Immune cells, microbial metabolites, and $\alpha$-syn aggregates that originate from the appendix and enter the brain via the BBB have the potential to contribute to PD. The BBB is a physical, semipermeable barrier formed by endothelial cells through interactions with pericytes and astrocytes. It helps protect the brain from circulating solutes, toxins, immune cells, and pathogens. Monomeric $\alpha$-syn can disrupt the BBB by interacting with pericytes [133]. Lipopolysaccharides, pro-inflammatory cytokines, $\mathrm{T}$ helper cells, and monocytes can also increase BBB permeability [134]. Neuroimaging studies of PD patients show that the BBB is compromised [135] and that there is an increase in $T$ cells in the substantia nigra of PD patients relative to healthy, age-matched controls 


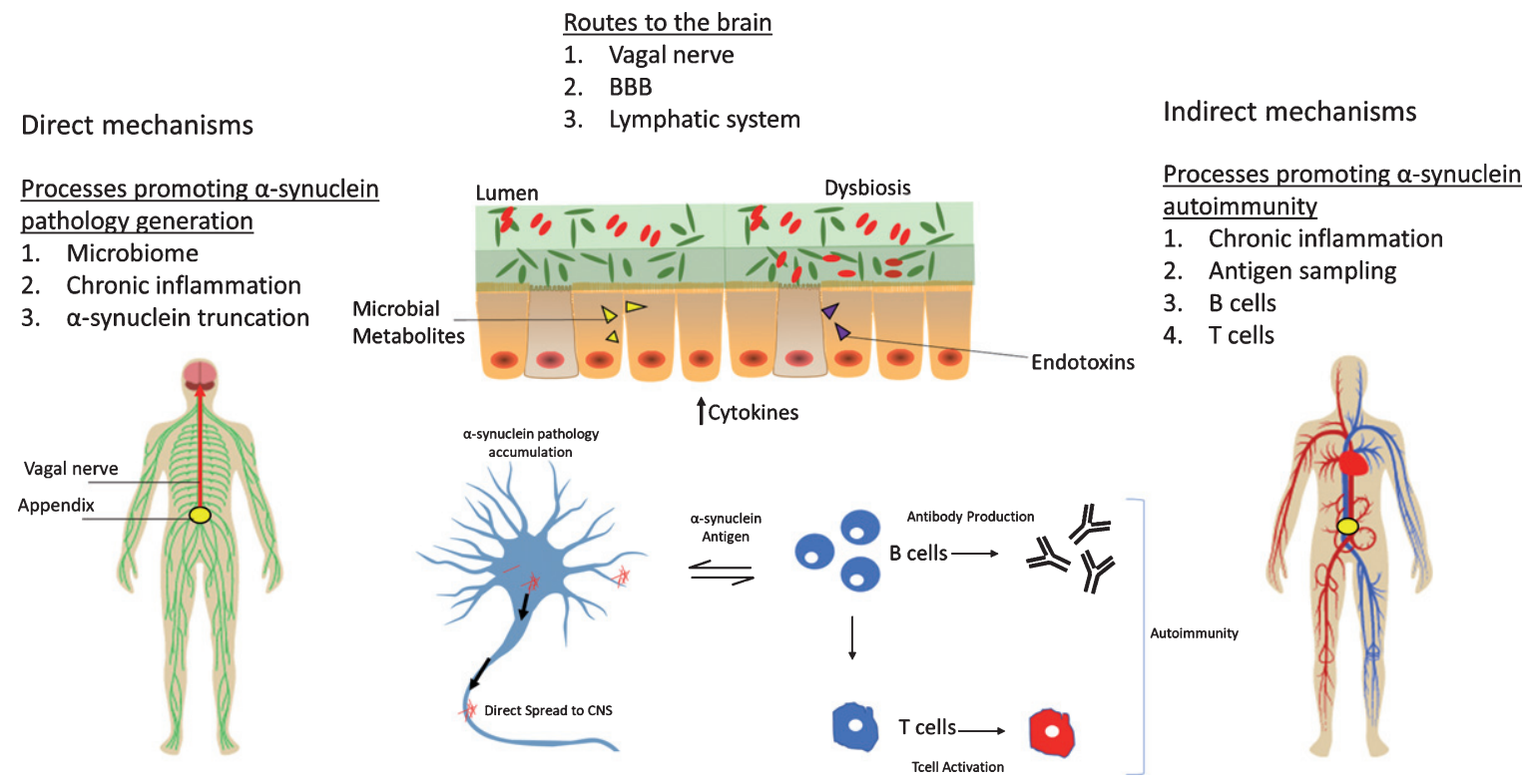

Fig. 1. The appendix as an initiation site for PD. Several possible mechanisms for the role of the appendix in PD are depicted. The appendix microbiota could influence PD by promoting cytokine release or by the release of endotoxins and/or bacterial metabolites (e.g., short-chain fatty acids). Disruption of the dual mucous layers in the appendix or microbial biofilm penetration of the inner mucous layer could result in host invasion of pathogenic microorganisms. Dysbiosis promotes a state of chronic tissue inflammation that results in the accumulation of $\alpha$-syn pathology and aggregation-prone $\alpha$-syn truncation products. $\alpha$-Syn pathology can then propagate to the brain via the vagus nerve to initiate PD. Alternatively or in addition, $\alpha$-syn pathology may accumulate in the brain via the circulatory system and a compromised BBB integrity or via a degenerating lymphatic system. Another mechanism could involve chronic tissue inflammation that upregulates $\alpha$-syn, which in turn may act as an antigen to stimulate B cells, resulting in the production of autoreactive immunoglobulin and T cells. The activation of these peripheral immune cells might then lead to systemic autoimmunity toward $\alpha$-syn. Both autoantibodies and self-reactive T cells might enter the CNS, resulting in neurotoxicity and PD.

[136]. Mouse models of PD also demonstrate the infiltration of T cells during the disease course [136]. Dopaminergic neurons in the substantia nigra of the human brain are capable of antigen presentation, which renders them susceptible to T-cell mediated neurodegeneration in vitro [137]. Increased T cell recognition of $\alpha$-syn peptides has been observed in PD [103]. Because the appendix is rich in adaptive immune cells and hosts a high amount of $\alpha$-syn, it is a prime site for the development of autoreactive immune cells directed against $\alpha$-syn. T cells have been shown to migrate from GALT, like the appendix, to non-lymphoid tissues [138]. Hence, it is interesting to speculate that the appendix may be a source of autoreactive $\mathrm{T}$ cells that invade the brain via a compromised BBB, with subsequent destruction of local $\alpha$-syn-presenting brain neurons. Consistent with this idea, immune cells originating from the gut have been found to transit to the brain and influence neuroinflammation [139, 140]. Immune activation in the GI tract, including in the appendix, may also contribute to the elevated levels of circulating cytokines found in PD patients, which further reduces BBB integrity and promotes neuroinflammation [141-143].

As a secondary lymphoid organ, the appendix is part of the lymphatic system. The brain lymphatic system is segregated from the blood vascular system and is an anatomical route by which interstitial fluid, immune cells, and cellular debris are conveyed. For example, brain lymphatic vessels play an important role in the clearance of amyloid $\beta$, extracellular tau, and other neurotoxic waste in a glymphatic process that is active especially during deep (slow-wave) sleep [126, 130, 144-146]. Blocking meningeal drainage aggravates PD-like pathology in mice that overexpress mutated $\alpha$-syn [147]. Furthermore, there is an age-dependent impairment in lymphatic drainage, which contributes to the buildup of brain amyloid pathology and the manifestation of cognitive decline in Alzheimer's disease [130]. Hence, the PD brain may undergo a loss of clearance of $\alpha$-syn aggregates arriving from the appendix (via the vagus nerve) due to the deterioration of the lymphatic vessels with aging. 


\section{REMOVAL OF THE APPENDIX AND PD RISK}

Several studies looking at the effect of appendectomy and clinical presentation of PD have conflicting conclusions [13, 15-17]. Some studies have found appendectomy to be associated with a reduction in risk for developing PD [5, 13], while others have found no effect $[15,17]$, or even increased risk [16, 17]. A possible explanation for the discrepancy is the follow-up time, which appears to be critical for assessing appendix contributions to PD [5]. Appendectomies most often occur in early adulthood (in the 20 's [148, 149]), and to accurately identify appendectomized and non-appendectomized cases, it is necessary to have the surgical history of a study cohort in early adulthood (to avoid misclassification bias towards a null effect). A prolonged follow-up length is consequently required because the onset of classical motor symptoms of PD (i.e., clinical diagnosis) is most common at greater than 60 years of age. Furthermore, PD pathogenesis is considered to begin years before motor symptom onset, and for appendectomy to influence the risk of triggering PD, it is necessary to assess patients with an early appendectomy, before the decades-long prodromal period [150]. This also circumvents potential confounding effects of constipation [151], an early prodromal symptom of PD [150]. Hence, a patient who has an appendectomy in early adulthood would need to have a follow-up period of presumably $40+$ years to determine clinical diagnosis of PD. The two largest studies available had follow-up periods of 10-34 years [16] and of up to 52 years [5], with the latter concluding that appendectomy was associated with decreased risk for PD. Thus, further investigation, specifically with long follow-up periods, are needed to determine the contribution of the appendix to the development of PD.

\section{CONCLUSIONS}

The appendix may play a role in the pathogenesis of PD, but the exact mechanism remains unclear (See Fig. 1). The appendix could be a source of pathological $\alpha$-syn that propagates to the central nervous system, but a "second-hit" may be required for this phenomenon to occur. Factors like chronic inflammation, microbiome perturbations, formation of $\alpha$-syn truncation products, and impaired cellular clearance of $\alpha$-syn aggregates may serve to promote the generation and spread of pathology from the appendix to the brain. The vagus nerve, compromised BBB integrity, and/or age-dependent degeneration of the CNS lymphatic system may be routes by which $\alpha$-syn seeds accumulate in the brain. Alternatively (or in addition), immunosurveillance functions of the appendix may contribute to acquiring autoimmunity towards $\alpha$ syn, including the generation of self-reactive $\mathrm{T}$ cells and autoantibodies. Hence, studying the accumulation and possible spreading of $\alpha$-syn from appendix to brain could help our understanding of the origins of PD.

Because $\alpha$-syn aggregates in the appendix are not disease-specific (i.e., they are observed in healthy patients as well), more refined analyses of $\alpha$-syn conformers, seeding, and excess in the PD appendix may be beneficial for diagnostic and prognostic purposes. Furthermore, the efficacy of antibody-based therapies against $\alpha$-syn excess may be measurable in the appendix. Clinical trials for $\alpha$-syn immunotherapy and depletion are ongoing, and they include compounds targeting $\alpha$-syn in the GI tract (NCT031001 49, NCT03047629, NCT03781791) [152]. Immunosuppressants have been associated with lowered PD risk [114, 153], and their effect on $\alpha$-syn pathology may be detectable in the appendix. Recent clinical trials directed to the PD microbiome have also begun (NCT03575195, NCT03667404), and the robustness and durability of microbiome-based therapies may benefit from modifying the microbiota in the appendix. Therefore, the appendix offers an appealing gateway to access the immune system, microbiome, and $\alpha$-syn pathology within the intestine to benefit the development of a new generation of the therapies for PD that extend beyond the brain.

\section{ACKNOWLEDGMENTS}

V.L. is supported by grants from the Department of Defense (W81XWH1810512), the National Institute of Neurological Disorders and Stroke (1R21NS112614-01), and a Gibby \& Friends vs. Parky Award.

\section{CONFLICT OF INTEREST}

The authors have no conflict of interest to report.

\section{REFERENCES}

[1] Smith HF, P W, SH K, M L (2017) Morphological evolution of the mammalian cecum and cecal appendix. Comptes Rendus Palevol 16, 39-57. 
[2] Vitetta L, Chen J, Clarke S (2019) The vermiform appendix: An immunological organ sustaining a microbiome inoculum. Clin Sci (Lond) 133, 1-8.

[3] Palestrant D, Holzknecht ZE, Collins BH, Parker W, Miller SE, Bollinger RR (2004) Microbial biofilms in the gut: Visualization by electron microscopy and by acridine orange staining. Ultrastruct Pathol 28, 23-27.

[4] Masahata K, Umemoto E, Kayama H, Kotani M, Nakamura S, Kurakawa T, Kikuta J, Gotoh K, Motooka D, Sato S, Higuchi T, Baba Y, Kurosaki T, Kinoshita M, Shimada Y, Kimura T, Okumura R, Takeda A, Tajima M, Yoshie O, Fukuzawa M, Kiyono H, Fagarasan S, Iida T, Ishii M, Takeda K (2014) Generation of colonic IgA-secreting cells in the caecal patch. Nat Commun 5, 3704.

[5] Killinger BA, Madaj Z, Sikora JW, Rey N, Haas AJ, Vepa $\mathrm{Y}$, Lindqvist D, Chen H, Thomas PM, Brundin P, Brundin L, Labrie V (2018) The vermiform appendix impacts the risk of developing Parkinson's disease. Sci Transl Med 10, eaar5280.

[6] Stokholm MG, Danielsen EH, Hamilton-Dutoit SJ, Borghammer P (2016) Pathological alpha-synuclein in gastrointestinal tissues from prodromal Parkinson disease patients. Ann Neurol 79, 940-949.

[7] Li JY, Englund E, Holton JL, Soulet D, Hagell P, Lees AJ, Lashley T, Quinn NP, Rehncrona S, Bjorklund A, Widner H, Revesz T, Lindvall O, Brundin P (2008) Lewy bodies in grafted neurons in subjects with Parkinson's disease suggest host-to-graft disease propagation. Nat Med 14, 501-503.

[8] Luk KC, Kehm V, Carroll J, Zhang B, O'Brien P, Trojanowski JQ, Lee VM (2012) Pathological alpha-synuclein transmission initiates Parkinson-like neurodegeneration in nontransgenic mice. Science 338, 949-953.

[9] Hilton D, Stephens M, Kirk L, Edwards P, Potter R, Zajicek J, Broughton E, Hagan H, Carroll C (2014) Accumulation of alpha-synuclein in the bowel of patients in the preclinical phase of Parkinson's disease. Acta Neuropathol 127, 235-241.

[10] Holmqvist S, Chutna O, Bousset L, Aldrin-Kirk P, Li W, Bjorklund T, Wang ZY, Roybon L, Melki R, Li JY (2014) Direct evidence of Parkinson pathology spread from the gastrointestinal tract to the brain in rats. Acta Neuropathol 128, 805-820.

[11] Ulusoy A, Rusconi R, Perez-Revuelta BI, Musgrove RE, Helwig M, Winzen-Reichert B, Di Monte DA (2013) Caudo-rostral brain spreading of alpha-synuclein through vagal connections. EMBO Mol Med 5, 1119-1127.

[12] Kim S, Kwon SH, Kam TI, Panicker N, Karuppagounder SS, Lee S, Lee JH, Kim WR, Kook M, Foss CA, Shen C, Lee H, Kulkarni S, Pasricha PJ, Lee G, Pomper MG, Dawson VL, Dawson TM, Ko HS (2019) Transneuronal propagation of pathologic alpha-synuclein from the gut to the brain models Parkinson's disease. Neuron 103, 627641 e627.

[13] Mendes A, Goncalves A, Vila-Cha N, Moreira I, Fernandes J, Damasio J, Teixeira-Pinto A, Taipa R, Lima AB, Cavaco S (2015) Appendectomy may delay Parkinson's disease onset. Mov Disord 30, 1404-1407.

[14] Palacios N, Hughes KC, Cereda E, Schwarzschild MA, Ascherio A (2018) Appendectomy and risk of Parkinson's disease in two large prospective cohorts of men and women. Mov Disord 33, 1492-1496.

[15] Yilmaz R, Bayram E, Ulukan C, Altinok MK, Akbostanci MC (2017) Appendectomy history is not related to Parkinson's disease. J Parkinsons Dis 7, 347-352.
[16] Svensson E, Horvath-Puho E, Stokholm MG, Sorensen HT, Henderson VW, Borghammer P (2016) Appendectomy and risk of Parkinson's disease: A nationwide cohort study with more than 10 years of follow-up. Mov Disord 31, 1918-1922.

[17] Marras C, Lang AE, Austin PC, Lau C, Urbach DR (2016) Appendectomy in mid and later life and risk of Parkinson's disease: A population-based study. Mov Disord 31, 12431247.

[18] Rolli-Derkinderen M, Leclair-Visonneau L, Bourreille A, Coron E, Neunlist M, Derkinderen P (2019) Is Parkinson's disease a chronic low-grade inflammatory bowel disease? J Neurol, doi: 10.1007/s00415-019-09321-0

[19] Breen DP, Halliday GM, Lang AE (2019) Gut-brain axis and the spread of alpha-synuclein pathology: Vagal highway or dead end? Mov Disord 34, 307-316.

[20] Kim JJ, Bandres-Ciga S (2019) The appendix and the risk of Parkinson's disease: Appended notes on correlation and causation. Mov Disord 34, 199.

[21] Darwin C (1871) The descent of man, and selection in relation to sex. John Murray, London, UK.

[22] Smith HF, Parker W, Kotze SH, Laurin M (2013) Multiple independent appearances of the cecal appendix in mammalian evolution and an investigation of related ecological and anatomical factors. Comptes Rendus Palevol 12, 339-354.

[23] Smith HF, Fisher RE, Everett ML, Thomas AD, Bollinger RR, Parker W (2009) Comparative anatomy and phylogenetic distribution of the mammalian cecal appendix. $J$ Evol Biol 22, 1984-1999.

[24] Zahid A (2004) The vermiform appendix: Not a useless organ. J Coll Physicians Surg Pak 14, 256-258.

[25] Marchetti M, Sirard JC, Sansonetti P, Pringault E, Kerneis S (2004) Interaction of pathogenic bacteria with rabbit appendix $\mathrm{M}$ cells: Bacterial motility is a key feature in vivo. Microbes Infect 6, 521-528.

[26] Ishimoto Y, Tomiyama-Miyaji C, Watanabe H, Yokoyama H, Ebe K, Tsubata S, Aoyagi Y, Abo T (2004) Agedependent variation in the proportion and number of intestinal lymphocyte subsets, especially natural killer T cells, double-positive CD4+ CD8+ cells and B220+ T cells, in mice. Immunology 113, 371-377.

[27] Fujihashi K, McGhee JR, Lue C, Beagley KW, Taga T, Hirano T, Kishimoto T, Mestecky J, Kiyono H (1991) Human appendix B cells naturally express receptors for and respond to interleukin 6 with selective $\operatorname{IgA} 1$ and $\operatorname{Ig} \mathrm{A} 2$ synthesis. J Clin Invest 88, 248-252.

[28] Bjerke K, Brandtzaeg P, Rognum TO (1986) Distribution of immunoglobulin producing cells is different in normal human appendix and colon mucosa. Gut 27, 667-674.

[29] Bollinger R, Barbas AS, Bush EL, Lin SS, Parker W (2007) Biofilms in the large bowel suggest an apparent function of the human vermiform appendix. J Theor Biol 249, 826831.

[30] Sicard JF, Le Bihan G, Vogeleer P, Jacques M, Harel J (2017) Interactions of Intestinal Bacteria with Components of the Intestinal Mucus. Front Cell Infect Microbiol $7,387$.

[31] Johansson ME, Larsson JM, Hansson GC (2011) The two mucus layers of colon are organized by the MUC2 mucin, whereas the outer layer is a legislator of host-microbial interactions. Proc Natl Acad Sci U S A 108(Suppl 1), 46594665.

[32] Swidsinski A, Loening-Baucke V, Theissig F, Engelhardt H, Bengmark S, Koch S, Lochs H, Dorffel Y (2007) Com- 
parative study of the intestinal mucus barrier in normal and inflamed colon. Gut 56, 343-350.

[33] Poewe W (2008) Non-motor symptoms in Parkinson's disease. Eur J Neurol 15(Suppl 1), 14-20.

[34] Muller B, Assmus J, Herlofson K, Larsen JP, Tysnes OB (2013) Importance of motor vs. non-motor symptoms for health-related quality of life in early Parkinson's disease. Parkinsonism Relat Disord 19, 1027-1032.

[35] Volpicelli-Daley LA, Luk KC, Patel TP, Tanik SA, Riddle DM, Stieber A, Meaney DF, Trojanowski JQ, Lee VM (2011) Exogenous alpha-synuclein fibrils induce Lewy body pathology leading to synaptic dysfunction and neuron death. Neuron 72, 57-71.

[36] Mao X, Ou MT, Karuppagounder SS, Kam TI, Yin X, Xiong Y, Ge P, Umanah GE, Brahmachari S, Shin JH, Kang HC, Zhang J, Xu J, Chen R, Park H, Andrabi SA, Kang SU, Goncalves RA, Liang Y, Zhang S, Qi C, Lam S, Keiler JA, Tyson J, Kim D, Panicker N, Yun SP, Workman CJ, Vignali DA, Dawson VL, Ko HS, Dawson TM (2016) Pathological alpha-synuclein transmission initiated by binding lymphocyte-activation gene 3 . Science $\mathbf{3 5 3}$, aah3374.

[37] Braak H, Del Tredici K, Rub U, de Vos RA, Jansen Steur EN, Braak E (2003) Staging of brain pathology related to sporadic Parkinson's disease. Neurobiol Aging 24, 197211.

[38] Liu B, Fang F, Pedersen NL, Tillander A, Ludvigsson JF, Ekbom A, Svenningsson P, Chen H, Wirdefeldt K (2017) Vagotomy and Parkinson disease: A Swedish registerbased matched-cohort study. Neurology 88, 1996-2002.

[39] Svensson E, Horvath-Puho E, Thomsen RW, Djurhuus JC, Pedersen L, Borghammer P, Sorensen HT (2015) Vagotomy and subsequent risk of Parkinson's disease. Ann Neurol 78, 522-529.

[40] Tysnes OB, Kenborg L, Herlofson K, Steding-Jessen M, Horn A, Olsen JH, Reichmann H (2015) Does vagotomy reduce the risk of Parkinson's disease? Ann Neurol 78, 1011-1012.

[41] Ulusoy A, Phillips RJ, Helwig M, Klinkenberg M, Powley TL, Di Monte DA (2017) Brain-to-stomach transfer of alpha-synuclein via vagal preganglionic projections. Acta Neuropathol 133, 381-393.

[42] Knudsen K, Fedorova TD, Hansen AK, Sommerauer M, Otto M, Svendsen KB, Nahimi A, Stokholm MG, Pavese N, Beier CP, Brooks DJ, Borghammer P (2018) In-vivo staging of pathology in REM sleep behaviour disorder: A multimodality imaging case-control study. Lancet Neurol 17, 618-628.

[43] Hawkes CH, Del Tredici K, Braak H (2007) Parkinson's disease: A dual-hit hypothesis. Neuropathol Appl Neurobiol 33, 599-614.

[44] Visanji NP, Brooks PL, Hazrati LN, Lang AE (2013) The prion hypothesis in Parkinson's disease: Braak to the future. Acta Neuropathol Commun 1, 2.

[45] Sampson TR, Debelius JW, Thron T, Janssen S, Shastri GG, Ilhan ZE, Challis C, Schretter CE, Rocha S, Gradinaru V, Chesselet MF, Keshavarzian A, Shannon KM, Krajmalnik-Brown R, Wittung-Stafshede P, Knight R, Mazmanian SK (2016) Gut microbiota regulate motor deficits and neuroinflammation in a model of Parkinson's disease. Cell 167, 1469-1480 e1412.

[46] Games D, Valera E, Spencer B, Rockenstein E, Mante M, Adame A, Patrick C, Ubhi K, Nuber S, Sacayon P, Zago W, Seubert P, Barbour R, Schenk D, Masliah E
(2014) Reducing C-terminal-truncated alpha-synuclein by immunotherapy attenuates neurodegeneration and propagation in Parkinson's disease-like models. J Neurosci 34, 9441-9454.

[47] Kellie JF, Higgs RE, Ryder JW, Major A, Beach TG, Adler CH, Merchant K, Knierman MD (2014) Quantitative measurement of intact alpha-synuclein proteoforms from post-mortem control and Parkinson's disease brain tissue by intact protein mass spectrometry. Sci Rep 4, 5797 .

[48] Grassi D, Howard S, Zhou M, Diaz-Perez N, Urban NT, Guerrero-Given D, Kamasawa N, Volpicelli-Daley LA, LoGrasso P, Lasmezas CI (2018) Identification of a highly neurotoxic alpha-synuclein species inducing mitochondrial damage and mitophagy in Parkinson's disease. Proc Natl Acad Sci U S A 115, E2634-E2643.

[49] Ulusoy A, Febbraro F, Jensen PH, Kirik D, RomeroRamos M (2010) Co-expression of C-terminal truncated alpha-synuclein enhances full-length alpha-synucleininduced pathology. Eur J Neurosci 32, 409-422.

[50] Luk KC, Song C, O’Brien P, Stieber A, Branch JR, Brunden KR, Trojanowski JQ, Lee VM (2009) Exogenous alpha-synuclein fibrils seed the formation of Lewy bodylike intracellular inclusions in cultured cells. Proc Natl Acad Sci U S A 106, 20051-20056.

[51] Giasson BI, Murray IV, Trojanowski JQ, Lee VM(2001) A hydrophobic stretch of 12 amino acid residues in the middle of alpha-synuclein is essential for filament assembly. J Biol Chem 276, 2380-2386.

[52] Li W, West N, Colla E, Pletnikova O, Troncoso JC, Marsh L, Dawson TM, Jakala P, Hartmann T, Price DL, Lee MK (2005) Aggregation promoting C-terminal truncation of alpha-synuclein is a normal cellular process and is enhanced by the familial Parkinson's disease-linked mutations. Proc Natl Acad Sci U S A 102, 2162-2167.

[53] Murray IV, Giasson BI, Quinn SM, Koppaka V, Axelsen PH, Ischiropoulos H, Trojanowski JQ, Lee VM (2003) Role of alpha-synuclein carboxy-terminus on fibril formation in vitro. Biochemistry 42, 8530-8540.

[54] Stolzenberg E, Berry D, Yang, Lee EY, Kroemer A, Kaufman S, Wong GCL, Oppenheim JJ, Sen S, Fishbein T, Bax A, Harris B, Barbut D, Zasloff MA (2017) A role for neuronal alpha-synuclein in gastrointestinal immunity. $J$ Innate Immun 9, 456-463.

[55] Beatman EL, Massey A, Shives KD, Burrack KS, Chamanian M, Morrison TE, Beckham JD (2015) Alphasynuclein expression restricts RNA viral infections in the brain. $J$ Virol 90, 2767-2782.

[56] Massey AR, Beckham JD (2016) Alpha-synuclein, a novel viral restriction factor hiding in plain sight. DNA Cell Biol 35, 643-645.

[57] Bhattacharyya D, Mohite GM, Krishnamoorthy J, Gayen N, Mehra S, Navalkar A, Kotler SA, Ratha BN, Ghosh A, Kumar R, Garai K, Mandal AK, Maji SK, Bhunia A (2019) Lipopolysaccharide from gut microbiota modulates alphasynuclein aggregation and alters its biological function. ACS Chem Neurosci 10, 2229-2236.

[58] Chen SG, Stribinskis V, Rane MJ, Demuth DR, Gozal E, Roberts AM, Jagadapillai R, Liu R, Choe K, Shivakumar B, Son F, Jin S, Kerber R, Adame A, Masliah E, Friedland RP (2016) Exposure to the functional bacterial amyloid protein curli enhances alpha-synuclein aggregation in aged Fischer 344 rats and Caenorhabditis elegans. Sci Rep 6, 34477. 
[59] Adler CH, Beach TG (2016) Neuropathological basis of nonmotor manifestations of Parkinson's disease. Mov Disord 31, 1114-1119.

[60] Beach TG, Corbille AG, Letournel F, Kordower JH, Kremer T, Munoz DG, Intorcia A, Hentz J, Adler $\mathrm{CH}$, Sue LI, Walker J, Serrano G, Derkinderen P (2016) Multicenter assessment of immunohistochemical methods for pathological alpha-synuclein in sigmoid colon of autopsied Parkinson's disease and control subjects. J Parkinsons Dis 6, 761-770.

[61] Killinger BA, Kordower JH (2019) Spreading of alphasynuclein - relevant or epiphenomenon? J Neurochem 150, 605-611.

[62] Manfredsson FP, Luk KC, Benskey MJ, Gezer A, Garcia J, Kuhn NC, Sandoval IM, Patterson JR, O'Mara A, Yonkers R, Kordower JH (2018) Induction of alphasynuclein pathology in the enteric nervous system of the rat and non-human primate results in gastrointestinal dysmotility and transient CNS pathology. Neurobiol Dis 112, 106-118.

[63] Fung TC, Olson CA, Hsiao EY (2017) Interactions between the microbiota, immune and nervous systems in health and disease. Nat Neurosci 20, 145-155.

[64] Yano JM, Yu K, Donaldson GP, Shastri GG, Ann P, Ma L, Nagler CR, Ismagilov RF, Mazmanian SK, Hsiao EY (2015) Indigenous bacteria from the gut microbiota regulate host serotonin biosynthesis. Cell 161, 264-276.

[65] Strandwitz P, Kim KH, Terekhova D, Liu JK, Sharma A, Levering J, McDonald D, Dietrich D, Ramadhar TR, Lekbua A, Mroue N, Liston C, Stewart EJ, Dubin MJ, Zengler K, Knight R, Gilbert JA, Clardy J, Lewis K (2019) GABAmodulating bacteria of the human gut microbiota. Nat Microbiol 4, 396-403.

[66] Valles-Colomer M, Falony G, Darzi Y, Tigchelaar EF, Wang J, Tito RY, Schiweck C, Kurilshikov A, Joossens M, Wijmenga C, Claes S, Van Oudenhove L, Zhernakova A, Vieira-Silva S, Raes J (2019) The neuroactive potential of the human gut microbiota in quality of life and depression. Nat Microbiol 4, 623-632.

[67] Han W, Tellez LA, Perkins MH, Perez IO, Qu T, Ferreira J, Ferreira TL, Quinn D, Liu ZW, Gao XB, Kaelberer MM, Bohorquez DV, Shammah-Lagnado SJ, de Lartigue G, de Araujo IE (2018) A neural circuit for gut-induced reward. Cell 175, 665-678 e623.

[68] Borovikova LV, Ivanova S, Zhang M, Yang H, Botchkina GI, Watkins LR, Wang H, Abumrad N, Eaton JW, Tracey KJ (2000) Vagus nerve stimulation attenuates the systemic inflammatory response to endotoxin. Nature 405, 458-462.

[69] Maslowski KM, Vieira AT, Ng A, Kranich J, Sierro F, Yu D, Schilter HC, Rolph MS, Mackay F, Artis D, Xavier RJ, Teixeira MM, Mackay CR (2009) Regulation of inflammatory responses by gut microbiota and chemoattractant receptor GPR43. Nature 461, 1282-1286.

[70] Sun M, Wu W, Chen L, Yang W, Huang X, Ma C, Chen F, Xiao Y, Zhao Y, Ma C, Yao S, Carpio VH, Dann SM, Zhao Q, Liu Z, Cong Y (2018) Microbiota-derived short-chain fatty acids promote $\mathrm{Th} 1$ cell IL-10 production to maintain intestinal homeostasis. Nat Commun 9, 3555.

[71] Guinane CM, Tadrous A, Fouhy F, Ryan CA, Dempsey EM, Murphy B, Andrews E, Cotter PD, Stanton C, Ross RP (2013) Microbial composition of human appendices from patients following appendectomy. MBio 4, e0036612.

[72] Gebbers JO, Laissue JA (2004) Bacterial translocation in the normal human appendix parallels the development of the local immune system. Ann N Y Acad Sci 1029, 337-343.

[73] Hapfelmeier S, Lawson MA, Slack E, Kirundi JK, Stoel M, Heikenwalder M, Cahenzli J, Velykoredko Y, Balmer ML, Endt K, Geuking MB, Curtiss R, 3rd, McCoy KD, Macpherson AJ (2010) Reversible microbial colonization of germ-free mice reveals the dynamics of $\operatorname{IgA}$ immune responses. Science 328, 1705-1709.

[74] Renz H, Brandtzaeg P, Hornef M (2011) The impact of perinatal immune development on mucosal homeostasis and chronic inflammation. Nat Rev Immunol 12, 9-23.

[75] Jackson HT, Mongodin EF, Davenport KP, Fraser CM, Sandler AD, Zeichner SL (2014) Culture-independent evaluation of the appendix and rectum microbiomes in children with and without appendicitis. PLoS One 9, e95414.

[76] Rogers MB, Brower-Sinning R, Firek B, Zhong D, Morowitz MJ (2016) Acute appendicitis in children is associated with a local expansion of fusobacteria. Clin Infect Dis 63, 71-78.

[77] Scheperjans F, Aho V, Pereira PA, Koskinen K, Paulin L, Pekkonen E, Haapaniemi E, Kaakkola S, Eerola-Rautio J, Pohja M, Kinnunen E, Murros K, Auvinen P (2015) Gut microbiota are related to Parkinson's disease and clinical phenotype. Mov Disord 30, 350-358.

[78] Qian Y, Yang X, Xu S, Wu C, Song Y, Qin N, Chen SD, Xiao Q (2018) Alteration of the fecal microbiota in Chinese patients with Parkinson's disease. Brain Behav Immun 70, 194-202.

[79] Bedarf JR, Hildebrand F, Coelho LP, Sunagawa S, Bahram M, Goeser F, Bork P, Wullner U (2017) Functional implications of microbial and viral gut metagenome changes in early stage L-DOPA-naive Parkinson's disease patients. Genome Med 9, 39.

[80] Perez-Pardo P, Dodiya HB, Engen PA, Forsyth CB, Huschens AM, Shaikh M, Voigt RM, Naqib A, Green SJ, Kordower JH, Shannon KM, Garssen J, Kraneveld AD, Keshavarzian A (2019) Role of TLR4 in the gut-brain axis in Parkinson's disease: A translational study from men to mice. Gut 68, 829-843.

[81] Scheperjans F, Derkinderen P, Borghammer P (2018) The gut and Parkinson's disease: Hype or hope? J Parkinsons Dis 8, S31-S39.

[82] Srivastav S, Neupane S, Bhurtel S, Katila N, Maharjan S, Choi H, Hong JT, Choi DY (2019) Probiotics mixture increases butyrate, and subsequently rescues the nigral dopaminergic neurons from MPTP and rotenone-induced neurotoxicity. J Nutr Biochem 69, 73-86.

[83] Barichella M, Pacchetti C, Bolliri C, Cassani E, Iorio L, Pusani C, Pinelli G, Privitera G, Cesari I, Faierman SA, Caccialanza R, Pezzoli G, Cereda E (2016) Probiotics and prebiotic fiber for constipation associated with Parkinson disease: An RCT. Neurology 87, 1274-1280.

[84] Sun MF, Zhu YL, Zhou ZL, Jia XB, Xu YD, Yang Q, Cui C, Shen YQ (2018) Neuroprotective effects of fecal microbiota transplantation on MPTP-induced Parkinson's disease mice: Gut microbiota, glial reaction and TLR4/TNF-alpha signaling pathway. Brain Behav Immun 70, $48-60$.

[85] Zhou ZL, Jia XB, Sun MF, Zhu YL, Qiao CM, Zhang BP, Zhao LP, Yang Q, Cui C, Chen X, Shen YQ (2019) Neuroprotection of fasting mimicking diet on MPTP-induced Parkinson's disease mice via gut microbiota and metabolites. Neurotherapeutics 16, 741-760.

[86] Im GY, Modayil RJ, Lin CT, Geier SJ, Katz DS, Feuerman M, Grendell JH (2011) The appendix may protect against 
Clostridium difficile recurrence. Clin Gastroenterol Hepatol 9, 1072-1077.

[87] Hanson NB, Lanning DK (2008) Microbial induction of $\mathrm{B}$ and $\mathrm{T}$ cell areas in rabbit appendix. Dev Comp Immunol 32, 980-991.

[88] Rhee KJ, Jasper PJ, Sethupathi P, Shanmugam M, Lanning D, Knight KL (2005) Positive selection of the peripheral $\mathrm{B}$ cell repertoire in gut-associated lymphoid tissues. $J$ Exp Med 201, 55-62.

[89] Rhee KJ, Sethupathi P, Driks A, Lanning DK, Knight KL (2004) Role of commensal bacteria in development of gut-associated lymphoid tissues and preimmune antibody repertoire. J Immunol 172, 1118-1124.

[90] Kawaguchi M, Nanno M, Umesaki Y, Matsumoto S, Okada Y, Cai Z, Shimamura T, Matsuoka Y, Ohwaki M, Ishikawa H (1993) Cytolytic activity of intestinal intraepithelial lymphocytes in germ-free mice is strain dependent and determined by $\mathrm{T}$ cells expressing gamma delta Tcell antigen receptors. Proc Natl Acad Sci U S A 90, 8591-8594.

[91] Bos NA, Kimura H, Meeuwsen CG, De Visser H, Hazenberg MP, Wostmann BS, Pleasants JR, Benner R, Marcus DM (1989) Serum immunoglobulin levels and naturally occurring antibodies against carbohydrate antigens in germ-free BALB/c mice fed chemically defined ultrafiltered diet. Eur J Immunol 19, 2335-2339.

[92] Musaelyan K, Egeland M, Fernandes C, Pariante CM, Zunszain PA, Thuret S (2014) Modulation of adult hippocampal neurogenesis by early-life environmental challenges triggering immune activation. Neural Plast 2014, 194396.

[93] Sharon G, Sampson TR, Geschwind DH, Mazmanian SK (2016) The central nervous system and the gut microbiome. Cell 167, 915-932.

[94] Ogbonnaya ES, Clarke G, Shanahan F, Dinan TG, Cryan JF, O'Leary OF (2015) Adult hippocampal neurogenesis is regulated by the microbiome. Biol Psychiatry 78, e7-9.

[95] Cai Z, Fan LW, Kaizaki A, Tien LT, Ma T, Pang Y, Lin S, Lin RC, Simpson KL (2013) Neonatal systemic exposure to lipopolysaccharide enhances susceptibility of nigrostriatal dopaminergic neurons to rotenone neurotoxicity in later life. Dev Neurosci 35, 155-171.

[96] Tauschmann M, Prietl B, Treiber G, Gorkiewicz G, Kump P, Hogenauer C, Pieber TR (2013) Distribution of CD4(pos) -, CD8(pos) - and regulatory T cells in the upper and lower gastrointestinal tract in healthy young subjects. PLoS One 8, e80362.

[97] Senda T, Dogra P, Granot T, Furuhashi K, Snyder ME, Carpenter DJ, Szabo PA, Thapa P, Miron M, Farber DL (2019) Microanatomical dissection of human intestinal T-cell immunity reveals site-specific changes in gut-associated lymphoid tissues over life. Mucosal Immunol 12, 378-389.

[98] Ermak TH, Steger HJ, Pappo J (1990) Phenotypically distinct subpopulations of $\mathrm{T}$ cells in domes and $\mathrm{M}$ cell pockets of rabbit gut-associated lymphoid tissues. Immunology 71, 530-537.

[99] Yamamoto W, Toyoda H, Xu DQ, Hanaki R, Morimoto M, Nakato D, Ito T, Iwamoto S, Bonno M, Tanaka S, Hirayama M (2018) CD3+ B-1a cells as a mediator of disease progression in autoimmune-prone mice. Mediators Inflamm 2018, 9289417.

[100] Andreu-Ballester JC, Perez-Griera J, Ballester F, ColomerRubio E, Ortiz-Tarin I, Penarroja Otero C (2007) Secretory immunoglobulin A ( $\operatorname{sg}$ A) deficiency in serum of patients with GALTectomy (appendectomy and tonsillectomy). Clin Immunol 123, 289-297.

[101] Kruglov AA, Grivennikov SI, Kuprash DV, Winsauer C, Prepens S, Seleznik GM, Eberl G, Littman DR, Heikenwalder M, Tumanov AV, Nedospasov SA (2013) Nonredundant function of soluble LTalpha3 produced by innate lymphoid cells in intestinal homeostasis. Science 342, 1243-1246.

[102] Scott KM, Kouli A, Yeoh SL, Clatworthy MR, WilliamsGray CH (2018) A systematic review and meta-analysis of alpha synuclein auto-antibodies in Parkinson's disease. Front Neurol 9, 815.

[103] Sulzer D, Alcalay RN, Garretti F, Cote L, Kanter E, AginLiebes J, Liong C, McMurtrey C, Hildebrand WH, Mao X, Dawson VL, Dawson TM, Oseroff C, Pham J, Sidney J, Dillon MB, Carpenter C, Weiskopf D, Phillips E, Mallal S, Peters B, Frazier A, Lindestam Arlehamn CS, Sette A (2017) T cells from patients with Parkinson's disease recognize alpha-synuclein peptides. Nature 546, 656-661.

[104] Pospisil R, Alexander CB, Obiakor H, Sinha RK, Mage RG (2006) CD5+ B cells are preferentially expanded in rabbit appendix: The role of CD5 in B cell development and selection. Dev Comp Immunol 30, 711-722.

[105] Somekh E, Serour F, Gorenstein A, Vohl M, Lehman D (2000) Phenotypic pattern of B cells in the appendix: Reduced intensity of CD19 expression. Immunobiology 201, 461-469.

[106] Sidman CL, Shultz LD, Hardy RR, Hayakawa K, Herzenberg LA (1986) Production of immunoglobulin isotypes by $\mathrm{Ly}-1+\mathrm{B}$ cells in viable motheaten and normal mice. Science 232, 1423-1425.

[107] Rothstein TL, Griffin DO, Holodick NE, Quach TD, Kaku H (2013) Human B-1 cells take the stage. Ann N Y Acad Sci 1285, 97-114.

[108] Dominguez-Villar M, Hafler DA (2018) Regulatory T cells in autoimmune disease. Nat Immunol 19, 665-673.

[109] Brudek T, Winge K, Folke J, Christensen S, Fog K, Pakkenberg B, Pedersen LO (2017) Autoimmune antibody decline in Parkinson's disease and Multiple System Atrophy; a step towards immunotherapeutic strategies. Mol Neurodegener 12, 44.

[110] Britschgi M, Olin CE, Johns HT, Takeda-Uchimura Y, LeMieux MC, Rufibach K, Rajadas J, Zhang H, Tomooka B, Robinson WH, Clark CM, Fagan AM, Galasko DR, Holtzman DM, Jutel M, Kaye JA, Lemere CA, Leszek J, Li G, Peskind ER, Quinn JF, Yesavage JA, Ghiso JA, Wyss-Coray T (2009) Neuroprotective natural antibodies to assemblies of amyloidogenic peptides decrease with normal aging and advancing Alzheimer's disease. Proc Natl Acad Sci U S A 106, 12145-12150.

[111] Devos D, Lebouvier T, Lardeux B, Biraud M, Rouaud T, Pouclet H, Coron E, Bruley des Varannes S, Naveilhan P, Nguyen JM, Neunlist M, Derkinderen P (2013) Colonic inflammation in Parkinson's disease. Neurobiol Dis 50, $42-48$.

[112] Weimers P, Halfvarson J, Sachs MC, Saunders-Pullman R, Ludvigsson JF, Peter I, Burisch J, Olen O (2019) Inflammatory bowel disease and Parkinson's disease: A nationwide Swedish cohort study. Inflamm Bowel Dis 25, 111-123.

[113] Villumsen M, Aznar S, Pakkenberg B, Jess T, Brudek T (2019) Inflammatory bowel disease increases the risk of Parkinson's disease: A Danish nationwide cohort study 1977-2014. Gut 68, 18-24. 
[114] Peter I, Dubinsky M, Bressman S, Park A, Lu C, Chen N, Wang A (2018) Anti-tumor necrosis factor therapy and incidence of Parkinson disease among patients with inflammatory bowel disease. JAMA Neurol 75, 939-946.

[115] Zhu F, Li C, Gong J, Zhu W, Gu L, Li N (2019) The risk of Parkinson's disease in inflammatory bowel disease: A systematic review and meta-analysis. Dig Liver Dis 51, 38-42.

[116] Park SH, Yang SK, Kim MJ, Yang DH, Jung KW, Kim KJ, Ye BD, Byeon JS, Myung SJ, Kim JH (2012) Long term follow-up of appendiceal and distal right-sided colonic inflammation. Endoscopy 44, 95-98.

[117] Andersson RE, Olaison G, Tysk C, Ekbom A (2001) Appendectomy and protection against ulcerative colitis. $N$ Engl J Med 344, 808-814.

[118] Rutgeerts P, D'Haens G, Hiele M, Geboes K, Vantrappen G (1994) Appendectomy protects against ulcerative colitis. Gastroenterology 106, 1251-1253.

[119] Frisch M, Pedersen BV, Andersson RE (2009) Appendicitis, mesenteric lymphadenitis, and subsequent risk of ulcerative colitis: Cohort studies in Sweden and Denmark. BMJ 338, b716.

[120] Kishimoto Y, Zhu W, Hosoda W, Sen JM, Mattson MP (2019) Chronic mild gut inflammation accelerates brain neuropathology and motor dysfunction in alpha-synuclein mutant mice. Neuromolecular Med 21, 239-249.

[121] Grathwohl S, Quansah E, Maroof N, Steiner JA, Spycher L, Benmansour F, Duran-Pacheco G, Siebourg-Polster J, Oroszlan-Szovik K, Remy H, Haenggi M, Stawiski M, Sehlhausen M, Maliver P, Wolfert A, Emrich T, Madaj Z, Escobar Galvis ML, Mueller C, Herrmann A, Brundin P, Britschgi M (2019) Experimental colitis drives enteric alpha-synuclein accumulation and Parkinson-like brain pathology. BioRxiv 505164; doi: https://doi.org/10.1101/ 505164.

[122] Watabe T, Nagaishi T, Tsugawa N, Kojima Y, Jose N, Hosoya A, Onizawa M, Nemoto Y, Oshima S, Nakamura T, Karasuyama H, Adachi T, Watanabe M (2018) B cell activation in the cecal patches during the development of an experimental colitis model. Biochem Biophys Res Commun 496, 367-373.

[123] Harnoy Y, Bouhnik Y, Gault N, Maggiori L, Sulpice L, Cazals-Hatem D, Boudjema K, Panis Y, Ogier-Denis E, Treton X (2016) Effect of appendicectomy on colonic inflammation and neoplasia in experimental ulcerative colitis. Br J Surg 103, 1530-1538.

[124] Krieglstein CF, Cerwinka WH, Laroux FS, Grisham MB, Schurmann G, Bruwer M, Granger DN (2001) Role of appendix and spleen in experimental colitis. J Surg Res 101, 166-175.

[125] Mizoguchi A, Mizoguchi E, Chiba C, Bhan AK (1996) Role of appendix in the development of inflammatory bowel disease in TCR-alpha mutant mice. J Exp Med 184, 707-715.

[126] Iliff JJ, Wang M, Liao Y, Plogg BA, Peng W, Gundersen GA, Benveniste H, Vates GE, Deane R, Goldman SA, Nagelhus EA, Nedergaard M (2012) A paravascular pathway facilitates CSF flow through the brain parenchyma and the clearance of interstitial solutes, including amyloid beta. Sci Transl Med 4, 147ra111.

[127] Louveau A, Smirnov I, Keyes TJ, Eccles JD, Rouhani SJ, Peske JD, Derecki NC, Castle D, Mandell JW, Lee KS, Harris TH, Kipnis J (2015) Structural and functional features of central nervous system lymphatic vessels. Nature 523, 337-341.
[128] Aspelund A, Antila S, Proulx ST, Karlsen TV, Karaman S, Detmar M, Wiig H, Alitalo K (2015) A dural lymphatic vascular system that drains brain interstitial fluid and macromolecules. J Exp Med 212, 991-999.

[129] Eide PK, Vatnehol SAS, Emblem KE, Ringstad G (2018) Magnetic resonance imaging provides evidence of glymphatic drainage from human brain to cervical lymph nodes. Sci Rep 8, 7194.

[130] Da Mesquita S, Louveau A, Vaccari A, Smirnov I, Cornelison RC, Kingsmore KM, Contarino C, Onengut-Gumuscu S, Farber E, Raper D, Viar KE, Powell RD, Baker W, Dabhi N, Bai R, Cao R, Hu S, Rich SS, Munson JM, Lopes MB, Overall CC, Acton ST, Kipnis J (2018) Functional aspects of meningeal lymphatics in ageing and Alzheimer's disease. Nature 560, 185-191.

[131] Louveau A, Herz J, Alme MN, Salvador AF, Dong MQ, Viar KE, Herod SG, Knopp J, Setliff JC, Lupi AL, Da Mesquita S, Frost EL, Gaultier A, Harris TH, Cao R, Hu S, Lukens JR, Smirnov I, Overall CC, Oliver G, Kipnis J (2018) CNS lymphatic drainage and neuroinflammation are regulated by meningeal lymphatic vasculature. Nat Neurosci 21, 1380-1391.

[132] Xu K, Lee JY, Kaneko Y, Tuazon JP, Vale F, van Loveren H, Borlongan CV (2019) Human stem cells transplanted into the rat stroke brain migrate to the spleen via lymphatic and inflammation pathways. Haematologica 104, 10621073.

[133] Dohgu S, Takata F, Matsumoto J, Kimura I, Yamauchi A, Kataoka Y (2019) Monomeric alpha-synuclein induces blood-brain barrier dysfunction through activated brain pericytes releasing inflammatory mediators in vitro. Microvasc Res 124, 61-66.

[134] Roy Sarkar S, Banerjee S (2019) Gut microbiota in neurodegenerative disorders. J Neuroimmunol 328, 98-104.

[135] Kortekaas R, Leenders KL, van Oostrom JC, Vaalburg W, Bart J, Willemsen AT, Hendrikse NH (2005) Blood-brain barrier dysfunction in parkinsonian midbrain in vivo. Ann Neurol 57, 176-179.

[136] Brochard V, Combadiere B, Prigent A, Laouar Y, Perrin A, Beray-Berthat $\mathrm{V}$, Bonduelle $\mathrm{O}$, Alvarez-Fischer D, Callebert J, Launay JM, Duyckaerts C, Flavell RA, Hirsch EC, Hunot S (2009) Infiltration of CD4+ lymphocytes into the brain contributes to neurodegeneration in a mouse model of Parkinson disease. J Clin Invest 119, 182-192.

[137] Cebrian C, Zucca FA, Mauri P, Steinbeck JA, Studer L, Scherzer CR, Kanter E, Budhu S, Mandelbaum J, Vonsattel JP, Zecca L, Loike JD, Sulzer D (2014) MHC-I expression renders catecholaminergic neurons susceptible to T-cellmediated degeneration. Nat Commun 5, 3633.

[138] Campbell DJ, Debes GF, Johnston B, Wilson E, Butcher EC (2003) Targeting $\mathrm{T}$ cell responses by selective chemokine receptor expression. Semin Immunol 15, 277 286.

[139] Rojas OL, Probstel AK, Porfilio EA, Wang AA, Charabati M, Sun T, Lee DSW, Galicia G, Ramaglia V, Ward LA, Leung LYT, Najafi G, Khaleghi K, Garcillan B, Li A, Besla R, Naouar I, Cao EY, Chiaranunt P, Burrows K, Robinson HG, Allanach JR, Yam J, Luck H, Campbell DJ, Allman D, Brooks DG, Tomura M, Baumann R, Zamvil SS, Bar-Or A, Horwitz MS, Winer DA, Mortha A, Mackay F, Prat A, Osborne LC, Robbins C, Baranzini SE, Gommerman JL (2019) Recirculating intestinal IgA-producing cells regulate neuroinflammation via IL-10. Cell 176, 610624 e618. 
[140] Wekerle H (2017) Brain autoimmunity and intestinal microbiota: 100 trillion game changers. Trends Immunol 38, 483-497.

[141] Reale M, Iarlori C, Thomas A, Gambi D, Perfetti B, Di Nicola M, Onofrj M (2009) Peripheral cytokines profile in Parkinson's disease. Brain Behav Immun 23, 55-63.

[142] Dobbs RJ, Charlett A, Purkiss AG, Dobbs SM, Weller C, Peterson DW (1999) Association of circulating TNFalpha and IL-6 with ageing and parkinsonism. Acta Neurol Scand 100, 34-41.

[143] Rentzos M, Nikolaou C, Andreadou E, Paraskevas GP, Rombos A, Zoga M, Tsoutsou A, Boufidou F, Kapaki E, Vassilopoulos D (2007) Circulating interleukin-15 and RANTES chemokine in Parkinson's disease. Acta Neurol Scand 116, 374-379.

[144] Patel TK, Habimana-Griffin L, Gao X, Xu B, Achilefu S, Alitalo K, McKee CA, Sheehan PW, Musiek ES, Xiong C, Coble D, Holtzman DM (2019) Dural lymphatics regulate clearance of extracellular tau from the CNS. Mol Neurodegener 14, 11.

[145] Goodman JR, Adham ZO, Woltjer RL, Lund AW, Iliff JJ (2018) Characterization of dural sinus-associated lymphatic vasculature in human Alzheimer's dementia subjects. Brain Behav Immun 73, 34-40.

[146] Shokri-Kojori E, Wang GJ, Wiers CE, Demiral SB, Guo M, Kim SW, Lindgren E, Ramirez V, Zehra A, Freeman C, Miller G, Manza P, Srivastava T, De Santi S, Tomasi D, Benveniste H, Volkow ND (2018) beta-Amyloid accumulation in the human brain after one night of sleep deprivation. Proc Natl Acad Sci U S A 115, 4483-4488.
[147] Zou W, Pu T, Feng W, Lu M, Zheng Y, Du R, Xiao M, Hu G (2019) Blocking meningeal lymphatic drainage aggravates Parkinson's disease-like pathology in mice overexpressing mutated alpha-synuclein. Transl Neurodegener $8,7$.

[148] Addiss DG, Shaffer N, Fowler BS, Tauxe RV (1990) The epidemiology of appendicitis and appendectomy in the United States. Am J Epidemiol 132, 910-925.

[149] Ashley DJ (1967) Observations on the epidemiology of appendicitis. Gut 8, 533-538.

[150] Kalia LV, Lang AE (2015) Parkinson's disease. Lancet 386, 896-912.

[151] Singh JP, Mariadason JG (2013) Role of the faecolith in modern-day appendicitis. Ann R Coll Surg Engl 95, 48-51.

[152] Jankovic J, Goodman I, Safirstein B, Marmon TK, Schenk DB, Koller M, Zago W, Ness DK, Griffith SG, Grundman M, Soto J, Ostrowitzki S, Boess FG, Martin-Facklam M, Quinn JF, Isaacson SH, Omidvar O, Ellenbogen A, Kinney GG (2018) Safety and tolerability of multiple ascending doses of PRX002/RG7935, an anti-alpha-synuclein monoclonal antibody, in patients with Parkinson disease: a randomized clinical trial. JAMA Neurol 75, 1206-1214.

[153] Racette BA, Gross A, Vouri SM, Camacho-Soto A, Willis AW, Searles Nielsen S (2018) Immunosuppressants and risk of Parkinson disease. Ann Clin Transl Neurol 5, 870875 . 